\title{
Responsibility Land Office of Semarang City In Terms Contained In Land Multiple Certificates
}

\begin{abstract}
Nur Ismi Hanifah ${ }^{1}$ and Umar Ma'ruf ${ }^{2}$
Abstract. Land as one of the natural resources that have a close relationship with human survival. Due to the imbalance between land supply in our country as a result of rapid population growth and increasing development, it can lead to various land disputes including multiple certificates. The purpose of this study to determine the cause of the double land certificate in Semarang and Semarang Land Office responsibilities in the event of multiple land certificates as well as the barriers and solutions Land Office responsibilities in the completion of the double land certificate in Semarang.

The method used in this research is the method of juridical-sociological. Specifications are descriptive analytical research. The data used primary data and secondary data obtained by interview and literature study. Qualitative data analysis, the problem was analyzed by the theory of the legal system, legal certainty and legal responsibilities.

The results showed that the cause of the land multiple certificates in the Land Office of Semarang is the first that structure, that possible errors and omissions of agencies, both which are substances that can be made possible on the legislation governing the registration of land and the third is Culture Law, uncaused of view of the society on land certificates. The responsibility of the Land Office of Semarang in It contained a land multiple certificates is the Regulation of the Minister of ATR / BPN No. 11 of 2016 on the Settlement of Cases of Land, which is after all the research is done, the land office is obliged to cancel one of them if there were procedural errors in the case of defective administration and conditions other rule. Obstacles Land Office in the completion of a land multiple certificates in Semarang is external (the parties are not present and not good faith when mediation) and internal (Land Office only as a mediator is not a court), so the solution in order to give rise to legal certainty then the settlement of disputes through State court and State Administrative court.

Keywords: Responsibility; Land; Associate Certificate.
\end{abstract}

\section{Introduction}

Land is very closely related to everyday human life, even human beings can be said any time relating to land. Everyone needs the land not only in his lifetime, but already dead still keep in touch with the ground. ${ }^{3}$

Therefore the agrarian law in Indonesia in general have been regulated in Act No. 5 of 1960 on Basic Regulation of Agrarian (BAL), which is the implementation of Article 33 paragraph (3) 1945. The existence of rapid population growth and rising development in our country resulting perceived need for land is increasing and urgent, while land supply increasingly narrow and difficult to hold. The imbalance between land supply with demand for land that can give rise to various land disputes. Basic Agrarian Law laid the foundation to achieve legal certainty and legal protection for all Indonesian

\footnotetext{
${ }^{1}$ Students Master of Notary Law, Faculty Law, UNISSULA, email: nurismihanifah@gmail.com

2 Lecturer of Faculty of Law UNISSULA, Semarang

${ }^{3}$ K. Wantjik Saleh, Hak Anda Atas Tanah, Jakarta: Ghalia Indonesia, 1982, p. 7.
} 
people. According to Article 19 BAL No. 5 of $1960^{4}$ who followed up with a letter of Article 3 of Government Regulation No. 24 of 1997 on Land Registration of Interest. Issuance of land certificates issued by the Land Office in the form of certificates of land property rights involving the applicant, the owner of the land adjoining the village administration and the agencies to get an explanation on the letters as a pad rights relating to the request for a certificate, so that an explanation of relevant parties have an opportunity to arise legal disability certificate. ${ }^{5}$ Based on the above, the authors conducted a study to obtain answers about the causes of land certificates doubles in Semarang and responsibilities of the Land Office of Semarang in the event of a land multiple certificates as well as the barriers and solutions the responsibility of the Land Office in the completion of a land multiple certificates in Semarang city.

\section{Research Methods}

The method used in this paper is the empirical jurisdiction. Thus, the juridical empirical approach in this research means is that in analyzing the problems made by combining the ingredients of the law (which is a secondary data) with the primary data collected in the field.

\section{Results and Discussion}

\subsection{Why of Land Certificate Associate at the Land Office of Semarang.}

Referring to some of the disputes that often happens lately the common cause of the emergence of land disputes can be grouped into two factors, namely, of legal and nonlegal factors.

- Legal factors

Some legal factors at the root of the conflict over land is often the case these days, among others. ${ }^{6}$ Overlapping of regulations, inadequate regulation, overlapping justice, Settlement and convoluted bureaucracy.

- Legal non factor

In addition to the above legal factors, the land conflict is also caused by some nonlegal factors, namely, ${ }^{7}$ Overlap the land use, land prices are higher, public awareness on land, the Land remained but the number keeps growing population, poverty

Certificates are awarded as a result of legal actions registration of land rights, as stipulated in Article 19 of Act No. 5 of 1960 on Basic Regulation of Agrarian (BAL), which reads:

Paragraph (1): In order to ensure legal certainty by government held land registration throughout the territory of Indonesia according to the regulations stipulated by

\footnotetext{
${ }^{4}$ Article 19 paragraph (1) Basic Agrarian Law No. 5 of 1960 states that, in order to ensure legal certainty, the government held land registration throughout the territory of the Republic of Indonesia in accordance with the provisions diataur by government regulation.

5 Ali Achmad Chomzah, 2003, Hukum Pertanahan Seri Hukum Pertanahan III-Penyelesaian Sengketa Hak Atas Tanah dan Seri Hukum Pertanahan IV-Pengadaan Tanah Instansi Pemerintah, Prestasi Pustaka, Jakarta, p. 18.

${ }^{6}$ Bernhard Limbong, 2012, Konflik Pertanahan, Jakarta : Margaretha Pustaha, p. 66.

${ }^{7}$ Ibid., p. 70.
} 
government regulations.

Paragraph (2): Enrollment in paragraph (1) shall include:

Measurement, mapping and wrapping land, registration of land rights and the transfer of those rights, granting letters of proof applicable right as evidentiary tool.

Cases of double the certificate always begins with the registration of land, as we know, that the land registration system adopted in the Law of Agrarian Indonesia, Act No. 5 of 1960 (BAL), that the normative juridical no way of land registration, the land registration systematically and sporadic land registration.

Land registration is the first time land registration activities for objects that have not been registered land under Government Regulation No. 10 of 1961 on Land Registration (PP No. 10 of 1961) or PP No 24 of 1997.

Land registration system that used a country depends on the legal principle adopted by the country to divert their rights. Meanwhile if the terms of the guarantee given to the provision of proof of rights letter as a means of proof, then timbulah different types of soil signup system, a system of positive publicity and negative publicity system.

In BAL adopted is a system of negative publicity that contains positive elements. It gives the sense that the registration system uses negative, which provides opportunities for third parties if he can prove that the land is his, then the person who first registered on the certificate can be implemented changes based on a court decision. While the positive element lies in the implementation of the registration system uses positive that registration. Each of these activities requires a considerable period of time and considerable expense, especially in measuring and mapping activities of each plot. So with the certificate of land ownership the greater the presence of a proof of rights that have been registered.

Based on the interview with Mr. Dian Puri Winasto, SH as the Head of Sub Section Handling Disputes, Conflict and Case Land at the Land Office of Semarang, while according to him that: ${ }^{8}$ "Many factors that cause multiple land certificates, there are various factors such as no plot, subject, supporting documents (the right base). In principle, if one field is owned by one object, one object that does not mean one person right of inheritance example example there are three people, has one the right base, will be issued 1 certificate if the measurement is correct, the administration is done properly it must issue one certificate. But if one of the subject and the right base there were 2, 1 plot has two subjects could have been prevented if the measuring correctly. Errors can occur on the subject, BPN, and issuing the right base. The most decisive factors that are measuring and maps. "

To analyze the factors that cause the occurrence of multiple certificates, it is necessary to theories about the legal system. And the theory of proper legal system as a related analysis of the factors that cause the occurrence of a double certificate is the theory of Lawrence M. Friedman.

Based on the theory of Friedman's system if the problems associated with the dual certificate basic assumptions about the factors that cause the occurrence of multiple certificates are of three elements.

From the first elements of the structure, it can be analyzed that the cause of the double certificate is possible the errors and omissions of the agency. The government, as the executor of the land registry of the Office of land as their fault boundary designation and comprehensive measurement plot by officers of the Land Office of

${ }^{8}$ Interview on July 2,2019 , At $10: 00 \mathrm{pm}$. 
Semarang, because the base map has not been computerized so that the base map is still not a single map.

The second element is the substance of it can be analyzed that the cause of the double certificate is made possible from the legislation governing land registration. Legislation governing land registration is possible not regulate in detail the processes and procedures related to registration of land so there is a gap onset of multiple certificates. For example, if a person already has a certificate on land issued by the Land Office of Semarang, but with Government Regulation No. 24 of 1997 provides an opportunity the other party to prove that he owns the actual ground, resulting in a legal dispute should be resolved in court over land.

The culture of the third element, namely the Law, it can be analyzed that the cause of the double certificate is possible of view of the society against the law. Which can be exemplified in the land measurement process. In Article 18 of Government Regulation No. 24 of 1997 affirms that in setting the boundaries of the land as far as possible the approval of holders of rights over land borders. But in fact the land-rights holders who wish to register their land regarded it does not really matter, because the way to get the land improperly or personal reasons that make the owner of the land adjacent to the land rights of the element of distrust.

So from there it is possible for error and there was a limit designation double certificates for their overlapping land rights certificates. Thus, it could be possible lawsuits related to the issuance of multiple certificates to the owners is deemed unlawful certificates of people who feel as the real owner.

\subsection{The Responsibility of the Land Office of Semarang in Case There is a Land Multiple Certificates}

Job and function Land Office of Semarang mentioned that one of the tasks of the Land Office of Semarang is assessment and treatment of problems, disputes, legal proceedings and the conflict in the land sector.

According to Article 27 and Article 28 of the Regulation of the Minister of Agrarian and Spatial Planning / Head of National Land Agency Number 38 Of 2016 concerning Organization and Regional Offices of the Land Agency and Land Office.

Land Office procedurally in Semarang in the field of land management and control issues are obliged to assess and deal with disputes with the research when it is known if there are any problems / overlap in issuing certificates.

Some things should be investigated by Land Office of Semarang in Article 10 of the Regulation of the Minister of ATR / BPN No. 11 of 2016 is the physical data and juridical; a judicial decision, the investigation report of the National Police, the Attorney RI, the Corruption Eradication Commission, or other document issued by the agency / law enforcement agencies; data issued or published by the competent authority; related data and can influence and clarify the issue sat Dispute and Conflict; and / or witness testimony.

After all the research is done, Land Office of Semarang obliged to cancel one of them if there are mistakes in the case of defective administrative procedures and the provisions contained in Article 11 (3) of the Regulation of the Minister of ATR / BPN No. 11 of 2016

After receiving the report and Conflict Settlement, Head of the Land Office of Semarang or the Minister resolve disputes and conflicts by issuing: 
- Cancellation Decisions Rights to Land; (Article 24 paragraph (2))

- Certificate Revocation Decision; (Article 24 paragraph (3))

- Decision Data Changes on the Certificate, Letter Measure, Land Book and / or other General Register; (Article 24 paragraph (4) or

- Notice that there is no clerical error.

In Article 24, paragraph (7) Permen ATR / BPN No. 11 2016, explained in above the ground plane are overlapping land rights certificates, the Minister or HeadLand Office of Semarang. The decision to revoke the authority issuing appropriate certificates overlap, so above the ground plane there is only one (1) certificate valid land rights. Dispute Resolution and Conflict in the form of Decree Cancellation Landrights or Certificate Revocation Decree, implementation is done in accordance with the authority of the cancellation.

The legal liability laws generally can be defined as a state ought to bear, assume responsibility, to bear everything, (if there is one thing, may be prosecuted, condemned, sued and so on) in accordance with applicable laws. Legal liability is man's consciousness of behavior or act that is intentional or unintentional. ${ }^{9}$

Based on the theory of responsibility if it is related to the responsibilities of the Land Office of Semarang in the event of a land multiple certificates, it can be analyzed that the Land Office had done his duty as an institution that issued the certificate and therefore the office of the Land of Semarang perform certificate revocation by issuing Decision Cancellation of certificates in the Minister ATR / BPN No. 11 of 2016 by issuing decrees Cancellation Rights to Land, Certificate Revocation Decision, Decision Data Changes on the Certificate, Letter Measure, Land Book and / or other General Register, or Notice that there is no clerical error.

\subsection{Obstacles and Solutions Responsibility Completion Multiple Certificates In the Land Office in Semarang}

The finishing dispute mechanisms that are generally adopted by the National Land Agency, there are two (2), namely:

- Through the completion of the Land Office of Semarang

Land disputes arising from their claims / complaints / objections from the public (individual / entity) that contains the truth and claims against a decision of the State Administration in the area of land that has been set by the official State Administration in the city, as well as the decision of officials can cause loss to the interested parties. So with the claim, interested parties receive administrative dispute resolution. The authority to make corrections to a decision of the state administration in the land sector is the Head of the Land Office of Semarang. The cancellation of the decision of the state administration in the area of land by the Head of the Land Office of Semarang based on their disability law / administration in the publication. Mediation outside the court in Indonesia dipayungi by Act No. 30 of 1999 on 47 Arbitration and Alternative Dispute Resolution, it can be seen in Article 6.

If the peace effort in the article referred to paragraph (6) can not be achieved then the settlement will be through the courts.

- Through the completion of Justice

${ }^{9}$ Purbacaraka, Perihal Kaedah Hukum, Citra Aditya, Bandung, 2010, p. 37. 
If settlement unilaterally from the Head of the Land Office of Semarang not be accepted by the parties to the dispute, the settlement must go through the court, of course, a court in the city of Semarang. To avoid problems in the future incur losses for the parties litigant or a third party, to the official State Administration in the field of Land concerned shall apply the general principles of good governance, namely to protect all parties concerned while awaiting ruling that already have permanent legal force. Then when there is the judge's decision that has the force of law is certain, then the head of the District Land Office / Municipality, certainly in Semarang via the Head Office of the Provincial National Land Agency, proposed the cancellation request to the Administrative Court of Semarang.

In relations with other human beings is already inevitable similarities and differences in the interests, views, and these differences can give birth to a dispute, disagreement or conflict. ${ }^{10}$

The paradigm of the development of non-litigation dispute resolution is not to replace the settlement in court, but that the use of alternative dispute resolution outside the court could also be a selection of the community to resolve disputes effectively and efficiently. ${ }^{11}$

Dispute resolution non-litigation can reduce the accumulation of cases in the courts, application of the principle is simple, fast, cost less and be completed within a period of 6 (six) months at the court having problems, because many cases are entered, the limited personnel qualified judges and professionals has expertise and use it as a job, and lack of support facilities. ${ }^{12}$

Under the rule of President Number 20 Of 2015 concerning the National Land Agency, the Land Office of Semarang has the authority to carry out the handling and settlement of land disputes. Tackling these problems through non-litigation or with a mediation conducted by the Land Office of Semarang to give effect to the decision of the settlement of the problem so that in addition to justice and expediency, as well as in the framework of certainty and legal protection, thus the title of the mediation conducted by Land Office Semarang city is authoritative. Thus, in the implementation of the handling of land disputes through mediation title at the Land Office of Semarang is not as easy as imagined.

According to the father of Dian Puri Winasto, $\mathrm{SH}$ as the Head of Sub Section Sekngketa Management, Conflict and Land Case Semarang, explains ${ }^{13}$

"We offer mediation settlement to the parties, however, not all the parties have agreed a deal that we offer, and the success of mediation in Semarang on average below $30 \% "$

In a mediation process, will be barriers or constraints faced by the Land Office of Semarang. If there is a constraint in the mediation process then will the efforts of the Land Office of Semarang while obstacles encountered are as follows:

- Constraints are derived from external factors are:

10 Husni, Penyelesaian Perselisihan Hubungan Industrial Melalui Pengadilan dan Di Luar Pengadilan, Jakarta: PT. Raja Gratindo Perkasa, 2004, p. 1.

${ }^{11}$ Khotbul Umam, Penyelesaian Sengketa Di Luar Pngadilan, Yogyakarta: Pustaka Yudistia, 2010, p. 7.

12 Takdir Rahmadi, Mediasi Penyelesaian Sengketa Melalui Pendekatan Mufakat, Jakarta: PT. Raja Grafindo Persada, 2010, p. 34-35.

${ }^{13}$ Interview on July 2, 2019, At 10:00 pm. 
- The absence of the parties to the dispute an effort to bring both parties to the dispute by the land office sometimes run into obstacles. In this case at the time specified in the law of the land office there of one of the parties is not present to meet the invitation, so that the mediation process can not be implemented because of the mediation should exist both parties directly concerned. Efforts Land Office of Semarang if the absence of the parties to the dispute is to strive once again. The procedure for holding back the process of mediation as the first attempt, with reiterated the invitation to the parties to the dispute and the other parties concerned. Furthermore, during the mediation after all parties to the dispute to the invitation, carried out as planned.

- There is no good faith of each of the parties to the dispute. Key to the success of efforts remedy land disputes through mediation is a good intention of each party, with regard to efforts to defend the interests of mastering the ground. In the implementation of mediation in the Land Office of Semarang, sometimes there are from one party is dishonest, by giving false evidence in the form of fake land certificates which can not immediately be authenticated when it was also in the mediation. It makes mediation becomes less conducive atmosphere. In this case of a mediator from the beginning the course of mediation made it clear to the parties that mediation voluntarily and in good faith to work together delivering true issues can be discussed without mutual awareness insistent with each. Land Office of Semarang has anticipated by studying the material previously existing problems, so as to condition the parties dishonestly give a rational explanation and moral exhortation.

- Constraints come from internal factors are:

The rules are considered to slow down the process of dispute resolution, because the position of the Land Office of Semarang as mediator can not be a breaker / court. Mediator only as a third party acting as a mediator, counselor, bridge and help find a solution on the parties to a dispute without having authority in decisionmaking. With the position of the Land Office of Semarang as a mediator who lack the functionality to cut, and every decision is returned to both sides, the land office considers the dispute settlement process seem to be very slow. During the mediation, the mediator only give advice and appealed to each of the parties to the dispute to re-examine on the basis of the common good. Therefore one of the important factors to consider Land Office of Semarang in this case the Head of the Assessment and Management of Land Disputes and Conflict Mediator is appointed Implementation team that has the knowledge and ability to mediate. Where they will be able to restore the course of the mediation process in order to function properly.

In Article 37 paragraph (1) Permen ATR / BPN No. 11 2016, if it turns out that the case of land disputes including disputes the authority of the Ministry, dispute settlement can be done through mediation.

If one party refuses to do mediation then the solution delivered to the parties in accordance with the provisions of the legislation.

Despite of various mediation contains many advantages, it does not mean there are no weaknesses. Mediation weakness lies in the "power tie" verdict on the dispute 
mediation beraspek purely civil, dispute settlement decision is directed solely by the parties. ${ }^{14}$

According to data obtained by the Land Office of Semarang not most of the parties, especially parties are not willing mediated teradu that the Land Office of Semarang recommend taking legal action through the District Court or the State Administrative Court (Administrative Court) in Semarang.

Legal certainty pointed to a clear law enforcement, remains, consistently and consequently the implementation of which can not be influenced by circumstances subjective nature. Certainty and justice is not just a moral imperative, but rather factual characterize the law. A law is uncertain and would not fair is not just bad law. According to Utrecht, legal certainty contains two meanings: first, the presence of the general regulation makes people know what conduct should or should not do, and secondly, in the form of legal security for the individual from the tyranny of the government because of the presence of the general regulation that individuals can know what you'll be charged or carried out by the State to the individual. ${ }^{15}$

Based on the theory of legal certainty above if it is associated with barriers and solutions the responsibility of the Land Office in the completion of a land multiple certificates in Semarang according to my analysis, in mediation barriers and solutions in solving double the certificate does not give rise to legal certainty for the settlement of disputes by means of mediation in Semarang no passion and mediator only as a mediator of the parties, plus some parties do not want to lose if the other party gets the advantage, for example, the size of the land is.

However, if the settlement of disputes through the District Court and the Court of Semarang City State Administration will be the legal certainty for in Article 55 of Government Regulation No. 24 of 1997 said that:

"BPN / Land Office should be subject to a court decision to cancel land certificate for the defeated party".

Therefore, all the problems related to the results of the court decision is legally binding and can not be disturbed contested.

\section{Closing}

\subsection{Conclusion}

Based on the research results, it can be concluded as follows:

- The cause of multiple certificates in the Land Office of Semarang, there are several factors, namely, the structure that causes multiple certificates are possible errors and omissions of the agency. The government, as the executor of land registration that the Land Office of Semarang as their fault boundary designation and comprehensive measurement plot by officers of the Land Office of Semarang, the substance that causes multiple certificates is made possible from the legislation governing land registration. Legislation governing land registration is possible not regulate in detail the processes and procedures related to registration of land so there is a gap onset of multiple certificates, and legal culture that causes multiple

14 Musyarofah, 2011, Mediasi Dalam Sengketa Pertanahan Di Kantor Pertanahan Kabupaten Pati, S-1 Fakultas Ilmu Sosial, UNNES, Semarang, p. 85.

${ }^{15}$ Riduan Syahrani, op., Cit. p. 23. 
certificates is possible of view of the society towards the rule of law where the land certificate. In Article 18 of Government Regulation No. 24 of 1997 affirms that in setting the boundaries of the land as far as possible the approval of holders of rights over land borders. in fact the land-rights holders who wish to register their land regarded it does not really matter.

- Accountability Land Office of Semarang in the event of a land multiple certificates, that the Land Office had done his duty as an institution that issued the certificate and therefore the office of the Land of Semarang cancellation in the Minister of ATR / BPN No. 11 of 2016 by issuing decrees Cancellation Rights to Land, Certificate Revocation decision, decision Data Changes on the Certificate, Letter Measure, Land Book and / or other General Register, or Notice that there is no clerical error.

- Obstacles and solutions the responsibility of the Land Office in the completion of a land multiple certificates in Semarang is in resolving disputes using the means of mediation barriers and solutions in solving double the certificate does not give rise to legal certainty for the settlement of disputes by means of mediation in Semarang no passion and mediators just as mediator, however if the settlement of disputes through the State court and State Administrative court of the existence of legal certainty because Article 55 of Government Regulation No. 24 of 1997 said that "BPN / land Office should be subject to a court decision to cancel land certificate for the defeated party".

\subsection{Suggestion}

Based on the above conclusions, the researchers can provide suggestions as follows:

- Semarang to the Land Office to be more effective in the resolution of land disputes against multiple certificates. In terms of the announcement through the media or against unscrupulous land registration officers who deviate in order to apply disciplinary sanctions as provided by law so that a deterrent effect.

- Land Office of Semarang should further improve the quality of human resources in this regard to the Head of Sub Section Handling Disputes relating to the mediation in the land in the city of Semarang.

- Land Office of Semarang for more socialization existence as an institution that could become public servants, who are able to seek settlement of land disputes in the city of Semarang.

\section{Bibliography}

\section{Book}

[1] Bernhard Limbong, 2012, Konflik Pertanahan, Jakarta: Margaretha Pustaha.

[2] Husni, 2004, Penyelesaian Perselisihan Hubungan Industrial Melalui Pengadilan dan Di Luar Pengadilan, Jakarta: PT. Raja Gratindo Perkasa.

[3] Khotbul Umam, 2010, Penyelesaian Sengketa Di Luar Pengadilan, Yogyakarta: Pustaka Yudistia.

[4] K. Wantjik Saleh, 1982, Hak Anda Atas Tanah, Jakarta: Ghalia Indonesia.

[5] Lutfi I Nasoetion, 2002, Konflik Pertanahan (Agraria) Menuju Keadilan Agraria), Bandung: Yayasan AKATIGA

[6] Purbacaraka, 2010, Perihal Kaedah Hukum, Bandung: Citra Aditya. 
[7] Takdir Rahmadi, 2010, Mediasi Penyelesaian Sengketa Melalui Pendekatan Mufakat, Jakarta: PT. Raja Grafindo Persada

\section{Constitution}

[1] Constitution Republic of Indonesia of 1945.

[2] Act No. 5 of 1960 on the basis of Regulation Agrarian

[3] Persiden Regulation No. 29 Of 2015 concerning the National Land Agency.

[4] Regulation of the Minister of ATR / BPN No. 11 of 2016 on the Settlement of Land case.

[5] Regulation of the Minister of ATR / BPN No. 38 of 2016 on the Organization and Regional Offices of the Land Agency and Land Office.

[6] Government Regulation No. 24 of 1997 on Land Registration. 